\title{
An AHP-fuzzy Approach for Evaluating the Commercial Bank Credits
}

\author{
Qiguang Zhang ${ }^{1}$ \\ ${ }^{1}$ School of Management, \\ Harbin Institute of Technology, \\ Haerbin, China
}

\author{
Wei Guo ${ }^{2}$ \\ ${ }^{2}$ School of Management, \\ Huazhong University of Science and Technology, \\ Wuhan, China
}

\begin{abstract}
Microfinance in China has entered the phase of rapid development and it has become one of the most important businesses in commercial banks. According to the principals of low carbon economy and the characteristics of farmer microfinance of Chinese commercial bank, this paper designed the performance evaluation system and evaluated the performance of small and micro businesses microfinance. In combination with the AHP and fuzzy comprehensive evaluation method, this paper analyzed the performance of microfinance of Harbin Bank and got a better evaluation results.
\end{abstract} fuzzy

Keywords-microfinance; performance evaluation; АНP;

\section{INTRODUCTION}

After the commercialization of Chinese microfinance in 2005, microfinance entered a high-speed development stage. The large-scale commercial banks tend to offer loans to large enterprises who have good credit and complete accounting records and they are not willing to offer loans to small and micro businesses who have incomplete accounting records and poor credit. Although the amount small and micro businesses need is small, the number of these businesses is very large and the market prospect is enormous. Now, Microfinance is regarded as an opportunity to expand by small and medium-sized banks.

Many performance evaluation systems can be used to evaluate banks' performance, such as "CAMEL" rating system, the standard \& poor's bank rating system, EVA and BSC. Gao Li, Fan Weidong [1] designed a performance evaluation system based on EVA to evaluate the performance of Chinese banks and found that listed banks were better than non-listed banks. Li Jianjun [2] evaluated the performance of top 85 banks in the world from scale, operating performance, security and development and found that improvement of operating performance, security and development can enhance Chinese banks' competitiveness. Stan, Tom [3] pointed out that BSC can improve financial performance and the performance of BSC is much better than traditional performance model. Yang Xuefeng [4] hold the view that commercial banks should design performance evaluation model based on BSC and KPI should be designed based on strategy from BSC's four dimensions. Liu Lei [5] thought that BSC can help small and medium-size banks break development bottleneck and build a management system which is designed based on bank's individual situation. Zhang Lijing [6] designed a performance evaluation system based on BSC and used it to evaluate the performance of a commercial bank in Hebei province. Prasad, Reddy, Cha [7] used "CAMEL" to evaluate the performance of India’s public banks. Wang Zheng, Wang Hao [8] pointed out that although BSC introduced nonfinancial indicators, these indicators did not reflect the shareholder value maximization. Therefore EVA should be used in BSC to compensate for its insufficiency.

This paper establishes a four dimension performance evaluation system for microfinance of commercial bank, and Fuzzy mathematics and AHP are used in the empirical analysis of performance of commercial bank microfinance to get a better evaluation results.

\section{Performance EVAluation SYSTEM For MiCROFinANCE}

This paper evaluates the performance of microfinance of commercial bank from four dimensions which are finance, customers, internal process, learning and growth. “Table 1 " is the performance evaluation system.

\section{COMPREHENSIVE EVALUATION MODEL BASED ON THE COMBINATION OF FUZZY MATHEMATICS AND AHP}

\section{A. AHP is used to determine the indicator weight}

To determine indicator weight, we issue questionnaires to experts. Experts establish the judgment matrix by comparing every level's indicator. After that, we calculate the indicator weight according to the theory of AHP.

We use comparison rating scale method to establish the judgment matrix. This method uses the ratio of the degree of importance of two factors to show the relative materiality (expressed by number of 1-9).

The score which a factor responses in the feature vector is the single ranking value of the importance to the upper level. To conduct the consistency check of the single ranking, the consistency indicator CI need to be calculated. In this formula, $\mathrm{n}$ is the number of matrix dimensions, $\lambda_{\max }$ is the maximum characteristic root. If the random consistency $\mathrm{CR}<0.10$, it means that the result of the level single ranking meets the consistency. If not, the judgment matrix should be adjusted. 
TABLE I Performance Evaluation Model.

\begin{tabular}{|c|c|c|}
\hline $\begin{array}{l}\text { First Class } \\
\text { Indicator }\end{array}$ & $\begin{array}{c}\text { Second Class } \\
\text { Indicator }\end{array}$ & Third Class Indicator \\
\hline \multirow[t]{19}{*}{ Finance } & \multirow[t]{4}{*}{ Security } & RAROC $x_{1}$ \\
\hline & & The impairment loss $\mathrm{x}_{2}$ \\
\hline & & Asset quality $\mathrm{x}_{3}$ \\
\hline & & Non-performing loan ratio $\mathrm{x}_{4}$ \\
\hline & \multirow[t]{6}{*}{ Development } & Profit growth rate $x_{5}$ \\
\hline & & EVA $_{6}$ \\
\hline & & $\begin{array}{l}\text { Percentage of revenue in total } \\
\text { revenue } x_{7}\end{array}$ \\
\hline & & Importance of microfinance $\mathrm{x}_{8}$ \\
\hline & & Growth rate of loan $\mathrm{x}_{9}$ \\
\hline & & Loan concentration $\mathrm{x}_{10}$ \\
\hline & \multirow[t]{4}{*}{ Profitability } & $\begin{array}{l}\text { Return on total assets of microfinance } \\
\qquad \mathrm{x}_{11}\end{array}$ \\
\hline & & Return on equity of microfinance $\mathrm{x}_{12}$ \\
\hline & & Net interest rate $x_{13}$ \\
\hline & & Net profit rate $\mathrm{x}_{14}$ \\
\hline & \multirow[t]{5}{*}{ Efficiency } & Before tax profit per person $\mathrm{x}_{15}$ \\
\hline & & Cost to revenue $\mathrm{x}_{16}$ \\
\hline & & Net profit to cost $x_{17}$ \\
\hline & & Amount of lending per person $\mathrm{x}_{18}$ \\
\hline & & $\begin{array}{l}\text { Amount of lending per Sub-branch } \\
\mathrm{x}_{19} \\
\end{array}$ \\
\hline \multirow[t]{8}{*}{ Customer } & \multirow[t]{3}{*}{ Satisfaction } & Growth rate of customers $x_{20}$ \\
\hline & & $\begin{array}{l}\text { Percentage of the regular customers } \\
\mathrm{X}_{21}\end{array}$ \\
\hline & & Retention rate $x_{22}$ \\
\hline & \multirow[t]{3}{*}{ Coverage } & Share of the stock market $x_{23}$ \\
\hline & & Share of the new market $\mathrm{x}_{24}$ \\
\hline & & Business success rate $x_{25}$ \\
\hline & \multirow[t]{2}{*}{ Improvement } & Customer income growth rate $\mathrm{x}_{26}$ \\
\hline & & Customer accession rate $\mathrm{x}_{27}$ \\
\hline \multirow{6}{*}{$\begin{array}{l}\text { Internal } \\
\text { process }\end{array}$} & & Percentage of professionals $\mathrm{X}_{28}$ \\
\hline & & Growth rate of professionals $\mathrm{x}_{29}$ \\
\hline & & Customers to staff $\mathrm{x}_{30}$ \\
\hline & & Approval time $\mathrm{x}_{31}$ \\
\hline & & $\begin{array}{l}\text { Efficiency of process improvement } \\
\mathrm{X}_{32} \\
\end{array}$ \\
\hline & & Corrective rate $x_{33}$ \\
\hline \multirow{7}{*}{$\begin{array}{l}\text { Learning } \\
\text { and growth }\end{array}$} & & Training investment rate $x_{34}$ \\
\hline & & Average training hour $\mathrm{x}_{35}$ \\
\hline & & Knowledge level of staff $x_{36}$ \\
\hline & & Staff turnover rate $x_{37}$ \\
\hline & & Staff induction rate $\mathrm{x}_{38}$ \\
\hline & & Quantity of service innovation $\mathrm{x}_{39}$ \\
\hline & & Products utilization rate $\mathrm{x}_{40}$ \\
\hline
\end{tabular}

The ranking value of the relative importance of all factors to the top level is called the top level ranking. To calculate it, the calculation should be conducted level by level. For example, if the upper level has $\mathrm{m}$ factors which are $b_{1}, b_{2}, \ldots, b_{m}$, weights are $w_{1}, w_{2}, \ldots, w_{m}$, and the lower level has $\mathrm{n}$ factors and their single ranking weights to $b_{j}$ are $c_{1 j}, c_{2 j}, \ldots, c_{n j}$, the importance to the upper level can be calculated by weighting.

\section{B. Fuzzy comprehensive evaluation model}

Fuzzy comprehensive evaluation model combines the AHP and fuzzy calculation. It uses AHP to determine the weight of each dimension and indicator of the performance evaluation system of microfinance, and the fuzzy calculation to determine the degree of membership, and at last, evaluates the performance of microfinance of commercial bank.

Step 1: Establish the comment set

We assume that $U=\left\{\mathrm{u}_{1}, \mathrm{u}_{2}, \mathrm{u}_{3}, \ldots, \mathrm{u}_{\mathrm{n}}\right\}$ is the set of $n$ elements of describing the evaluated object (indicators).

$G=\left\{g_{1}, g_{2}, g_{3}, \ldots, g_{m}\right\}$ is the set of $m$ judgments of describing the status of each element.

Comment set $\mathrm{G}$ is the set of possible results that given by the appraiser. $G_{j}$ is evaluation result, $m$ is the number of total possible evaluation results. Usually the comment set is divided into 3 to 5 levels.

Step 2: Determine the degree of membership

First level fuzzy comprehensive evaluation is to evaluate indicators of one dimension.

Step 3: First level fuzzy comprehensive evaluation

The comment set of the first level fuzzy comprehensive evaluation of dimension is:

$$
g_{i}=w_{i} \times f_{i}
$$

At the same time, the comment sets of the first level fuzzy comprehensive evaluation of other dimensions should be calculated.

Step 4: Second level fuzzy comprehensive evaluation

Second level fuzzy comprehensive evaluation is calculated based on the results of first level fuzzy comprehensive evaluation results. We can use following equation to get the result. According to the maximum membership principle, the evaluation result which has the maximum numerical value is the final evaluation result of the company.

$$
G=w\left(g_{1}, g_{2}, \ldots . ., g_{n}\right)^{T}
$$

IV. EMPIRICAL RESULTS OF THE PERFORMANCE EVALUATION

We use the AHP to calculate the weight of indicators of the performance evaluation system of farmer microfinance. We use the data from HARBIN Bank as the analytical samples, and evaluate the performance of microfinance.

\section{A. Determine the comment set}

We set five evaluation results which are: "excellent," "very good," "good,” "general," "poor.” The comment set is: 
$\mathrm{M}=\left\{\mathrm{m}_{1}, \mathrm{~m}_{2}, \mathrm{~m}_{3}, \mathrm{~m}_{4}, \mathrm{~m}_{5}\right\}=\{$ excellent, very good, good, general, poor $\}$

Four dimensions which affect the performance evaluation of microfinance are: "finance," "customer," "internal process," "learning and growth." Therefore, the factor set is:

$\mathrm{V}=\left\{\mathrm{v}_{1}, \mathrm{v}_{2}, \mathrm{v}_{3}, \mathrm{v}_{4}\right\}=$ finance, customer, internal process, learning and growth $\}$.

\section{B. Empirical results}

When calculating the degree of membership, the actual value of each indicator of the two branches will compare with the standard value which has five levels. We use their relative distance and the membership function to determine the degree of membership. According to the data of Harbin Bank from 2013, the degree of membership of each indicator is in "Table II."

According to the above results, the second level fuzzy comprehensive evaluation is shown in "Table III," and the first level fuzzy comprehensive evaluation is shown in “Table IV."

TABLE II.DEGREE OF HARBIN BANK.

\begin{tabular}{|c|c|c|c|c|c|}
\hline & $\mathrm{g} 1$ & $\mathrm{~g} 2$ & $\mathrm{~g} 3$ & $\mathrm{~g} 4$ & $\mathrm{~g} 5$ \\
\hline $\mathrm{X}_{1}$ & 0 & 0.43 & 0.57 & 0 & 0 \\
\hline $\mathrm{X}_{2}$ & 0 & 0.95 & 0.05 & 0 & 0 \\
\hline $\mathrm{X}_{3}$ & 0 & 0 & 0 & 0 & 1 \\
\hline $\mathrm{X}_{4}$ & 0 & 0 & 0 & 0.6 & 0.4 \\
\hline $\mathrm{X}_{5}$ & 1 & 0 & 0 & 0 & 0 \\
\hline $\mathrm{X}_{6}$ & 0.464884 & 0.535116 & 0 & 0 & 0 \\
\hline $\mathrm{X}_{7}$ & 0 & 0 & 0 & 1 & 0 \\
\hline $\mathrm{X}_{8}$ & 0 & 0.715 & 0.285 & 0 & 0 \\
\hline $\mathrm{X}_{9}$ & 0 & 0 & 0.131 & 0.869 & 0 \\
\hline $\mathrm{X}_{10}$ & 0 & 0 & 0.72625 & 0.27375 & 0 \\
\hline $\mathrm{X}_{11}$ & 0 & 0 & 0.545 & 0.455 & 0 \\
\hline $\mathrm{X}_{12}$ & 0 & 0 & 0 & 1 & 0 \\
\hline $\mathrm{X}_{13}$ & 0 & 0.52 & 0.48 & 0 & 0 \\
\hline $\mathrm{X}_{14}$ & 0 & 0.345 & 0.655 & 0 & 0 \\
\hline $\mathrm{X}_{15}$ & 0 & 0.327187 & 0.672813 & 0 & 0 \\
\hline $\mathrm{X}_{16}$ & 0 & 0 & 0 & 0 & 1 \\
\hline $\mathrm{X}_{17}$ & 0 & 0 & 0 & 0.16533 & 0.83467 \\
\hline $\mathrm{X}_{18}$ & 0 & 0.41133 & 0.58867 & 0 & 0 \\
\hline $\mathrm{X}_{19}$ & 0.099964 & 0.900036 & 0 & 0 & 0 \\
\hline $\mathrm{X}_{20}$ & 0 & 0.214439 & 0.785561 & 0 & 0 \\
\hline $\mathrm{X}_{21}$ & 0 & 0 & 0 & 0.875451 & 0.124549 \\
\hline $\mathrm{X}_{22}$ & 1 & 0 & 0 & 0 & 0 \\
\hline $\mathrm{X}_{23}$ & 0.404492 & 0.595508 & 0 & 0 & 0 \\
\hline $\mathrm{X}_{24}$ & 0 & 0.322438 & 0.677562 & 0 & 0 \\
\hline $\mathrm{X}_{25}$ & 0 & 0 & 0.72925 & 0.27075 & 0 \\
\hline $\mathrm{X}_{26}$ & 0.54827 & 0.45173 & 0 & 0 & 0 \\
\hline $\mathrm{X}_{27}$ & 0 & 0 & 0.561675 & 0.438325 & 0 \\
\hline $\mathrm{X}_{28}$ & 0 & 0.381099 & 0.618901 & 0 & 0 \\
\hline $\mathrm{X}_{29}$ & 0 & 0.414783 & 0.585217 & 0 & 0 \\
\hline $\mathrm{X}_{30}$ & 0 & 0.298237 & 0.701763 & 0 & 0 \\
\hline $\mathrm{X}_{31}$ & 0.875225 & 0.124775 & 0 & 0 & 0 \\
\hline $\mathrm{X}_{32}$ & 0 & 0.485714 & 0.514286 & 0 & 0 \\
\hline $\mathrm{X}_{33}$ & 0 & 0 & 0 & 0.761905 & 0.238095 \\
\hline $\mathrm{X}_{34}$ & 1 & 0 & 0 & 0 & 0 \\
\hline $\mathrm{X}_{35}$ & 0 & 0.624647 & 0.375353 & 0 & 0 \\
\hline $\mathrm{X}_{36}$ & 0 & 0 & 0.225915 & 0.774085 & 0 \\
\hline & & & & & \\
\hline
\end{tabular}

TABLE III. FIRST LEVEL FUZZY COMPREHENSIVE EVALUATION RESULTS.

\begin{tabular}{|c|c|c|c|c|c|c|}
\hline Dimension & Weight & $\mathrm{g}_{1}$ & $\mathrm{~g}_{2}$ & $\mathrm{~g}_{3}$ & $\mathrm{~g}_{4}$ & $\mathrm{~g}_{5}$ \\
\hline Finance & 0.47 & 0.082 & 0.276 & 0.253 & 0.215 & 0.171 \\
\hline Customer & 0.23 & 0.140 & 0.164 & 0.354 & 0.304 & 0.036 \\
\hline $\begin{array}{c}\text { Internal } \\
\text { process }\end{array}$ & 0.21 & 0.172 & 0.201 & 0.275 & 0.266 & 0.083 \\
\hline $\begin{array}{c}\text { Learning } \\
\text { and growth }\end{array}$ & 0.09 & 0.087 & 0.372 & 0.268 & 0.241 & 0 \\
\hline
\end{tabular}

TABLE IV. SECOND LEVEL FUZZY COMPREHENSIVE EVALUATION RESULTS.

\begin{tabular}{|c|c|c|c|c|c|}
\hline & $\mathrm{g}_{1}$ & $\mathrm{~g}_{2}$ & $\mathrm{~g}_{3}$ & $\mathrm{~g}_{4}$ & $\mathrm{~g}_{5}$ \\
\hline $\begin{array}{c}\text { Total } \\
\text { results }\end{array}$ & 0.1152 & 0.2433 & 0.2827 & 0.2491 & 0.1068 \\
\hline
\end{tabular}

According to the calculation results, we can get the degree of membership of the second level of fuzzy comprehensive evaluation. In combination with the comment set $\mathrm{M}=$ \{ excellent, very good, good, general, poor \}, the possibility of "good."

\section{CONCLUSIONS}

This paper established the performance evaluation system of microfinance of commercial bank. In combination with the AHP and fuzzy comprehensive evaluation method, we analyzed the performance of microfinance Harbin Bank and got the conclusions. The performance of microfinance in 2013 is "good."

\section{ACKNOWLEDGMENTS}

The work described in this paper is supported by a grant from Soft science fund of Department of science and technology, Hubei province (2013BDF009) and Huazhong University of Science and Technology Fundamental Research Funds for the Central Universities ("A research of performance evaluation of microfinance of small and medium sized commercial banks in the perspective of inclusive financial system”). 


\section{REFERENCES}

[1] Gao li, Fan Weidong, A study on the value-creating capability of banking industry in China. Finance \& Trade Economics, 11, pp. 26-33, 2003.

[2] Li Jianjun, Design and empirical analysis of an international comparison and evaluation system of commercial banks. Finance Forum, 9, pp. 34-39, 2004.

[3] Davis Stan, Albright Tom, An investigation of the effect of balanced scorecard implementation on financial performance. Management Accounting Research, 2, pp. 135-153, 2004.

[4] Yang Xuefeng, Research on the China's Commercial Bank Performance Evaluation System. Huazhong University of Science and Technology, 2006.
[5] Liu Lei, Analysis of the applicability of balanced scorecard for city commercial banks. Economic Research Guide, 34, pp. 66-67, 2010.

[6] Zhang Lijing, Comprehensive Performance Evaluation of Small and Medium Size Commercial Banks Based on Balanced Scorecard. Hebei .University, 2010.

[7] K.V.N. Prasad, R.D. Maheshwara, A. Chari, Performance evaluation of public sector banks in India: an application of camel model. International Journal of Research in Commerce and Management, 6, pp. 96-102, 2011.

[8] Wang Zheng, Wang Hao, Comparison of EVA and BSC and the comprehensive application. China Township Enterprises Accounting, 7, pp. 123-124, 2013. 